Marquette University

e-Publications@Marquette

College of Communication Faculty Research and

Publications

Communication, College of

$1-1-2001$

Public Perceptions of the Midwest's Pavements: Explaining the Relationship Between Pavement Quality and Driver Satisfaction

James K. Giese

Marquette University

Robert Griffin

Marquette University, robert.griffin@marquette.edu

David Kuemmel

Marquette University, david.kuemmel@marquette.edu

Accepted version. Transportation Research Record, Vol. 1769 (2001): 61-70. DOI. (C) 2001 National Academy of Sciences. Used with permission. 


\title{
Public Perceptions of the Midwest's Pavements: Explaining the Relationship Between Pavement Quality and Driver Satisfaction
}

\author{
David A. Kuemmel \\ Civil and Environmental Engineering, Marquette University \\ Milwaukee, WI \\ Robert J. Griffin \\ Journalism and Media Studies, Marquette University \\ Milwaukee, WI \\ James K. Giese \\ Center for Mass Media Research, Marquette University \\ Milwaukee, WI
}

A three-phase study involving focus groups and sample surveys was conducted in three Midwestern states to assess the amount of satisfaction that motorists who drive on rural, two-lane state highways have with the pavement characteristics of those highways and to explain the relationship between the actual physical condition of the pavements and motorists' satisfaction. Consistently in each state, the direct relationship between pavement quality and driver satisfaction was mediated by cognitive

Transportation Research Record, Vol. 1769 (2001): pg. 61-70. DOI. This article is @ National Academy of Sciences and permission has been granted for this version to appear in e-Publications@Marquette. National Academy of Sciences does not grant permission for this article to be further copied/distributed or hosted elsewhere without the express permission from National Academy of Sciences. 
structure-a set of five specific beliefs motorists have about the pavement. The part of the study that (a) applies a powerful psychological model to the task of understanding motorists' satisfaction with pavements; $(b)$ offers reliable measures of driver satisfaction with pavement quality and of beliefbased cognitive structure related to pavements; $(c)$ has accomplished the important task of identifying the most salient pavement features considered by members of the public when they evaluate pavement quality; and $(d)$ illustrates very clearly the importance of considering motorists' beliefs about the pavement, issues of trust, and aspects of the Fishbein's attitude model and Ajzen's theory of planned behavior when trying to predict or understand driver satisfaction are covered. Although the pavement management indices used by the state departments of transportation will continue to be used to establish thresholds for improvement triggers, these indices alone do not explain such broad concepts as satisfaction with a particular pavement.

Currently little is known about the how the public perceives pavement quality, and, historically, the public has had little involvement in the planning of public highways, which has led to what Khisty and Leleur termed "increased criticism of current-day planning practice" (1, p. 125). In general, there is a need for state departments of transportation (DOTs) to have information about the public's perceptions of state highways (2) and, more specifically, to have information about the conditions that lead to driver satisfaction. Pavement repair and management efforts are likely to lead to an increase in overall driver satisfaction if decisions are based on more extensive and comprehensive customer input.

To examine the public's perception of rural, two-lane highways, researchers at Marquette University conducted a 5-year study in Wisconsin, Iowa, and Minnesota, which was funded by FHWA and the three states as a Pooled Fund project. The primary goal of the project was to characterize customer input representatively as part of the continuing improvement of pavement policy, including (a) learning about the public's preferences for trade-offs in improvement scheduling, $(b)$ identifying important pavement attributes related to driver satisfaction, and $(c)$ explaining the nature of the relationship between pavement condition and overall driver satisfaction. The results of the first objective were reported by Robinson et al. in 2000 (3). Results of the second objective on thresholds of physical indices are described in Kuemmel et al. in a paper in this Record. This paper is primarily concerned with the third objective: to test formally the utility of a parsimonious psychological model that explains the relationship

Transportation Research Record, Vol. 1769 (2001): pg. 61-70. DOI. This article is (C) National Academy of Sciences and permission has been granted for this version to appear in e-Publications@Marquette. National Academy of Sciences does not grant permission for this article to be further copied/distributed or hosted elsewhere without the express permission from National Academy of Sciences. 
between physical pavement ratings, such as International Roughness Index (IRI), and self-reported driver satisfaction with the pavement surface.

\section{Background}

Data on the public perception of pavements date to the AASHO road tests in the 1950 s (4). During the road test, a pavement serviceability-rating panel subjectively rated sections of differing pavement types in Ottawa, Illinois, on a scale of zero to five. Roughness measurements were then performed on these sections using objective ratings from the CHLOE profilometer, a response-type road roughness measuring system named for its inventors. Analysis of the subjective and objective ratings were combined to develop two models for asphalt concrete and portland cement concrete pavements for converting the profile data to the public's perception of pavement serviceability (i.e., ride and distress) (5).

The Indiana DOT reported a study of public perceptions (6). Using 68 of what the department termed "typical Indiana drivers," it rated 66 test sections for $1 \mathrm{~km}(0.5 \mathrm{mi})$ each and found an 85 percent satisfaction rate for both concrete and asphalt pavements at a Present Serviceability Index (PSI) of 2.2 and at an IRI of 2.58 (6).

Colorado University reported a study for the Colorado DOT in 1990 evaluating the public perception of 24 individuals driven over 69 highway sections ( 51 bituminous and 18 concrete) in the Denver metro area at speeds of 56 and $89 \mathrm{~km} / \mathrm{h}$ (35 and $55 \mathrm{mph}$ ) (7). Pavement roughness was measured with a Mays ride meter. The study showed that 10 percent of the public was unhappy with asphalt pavements at the current serviceability index of 2.50 and 10 percent was unhappy with concrete pavements at a serviceability index of 2.21 (7).

In 1988, Wisconsin DOT reported an experiment designed to establish relationships between pavement roughness and user's perceived need to improve the road (8). Fifty randomly selected subjects were paid to drive 1 of 32 road segments of varying pavement quality with similar geometric characteristics. The study

Transportation Research Record, Vol. 1769 (2001): pg. 61-70. DOI. This article is (C) National Academy of Sciences and permission has been granted for this version to appear in e-Publications@Marquette. National Academy of Sciences does not grant permission for this article to be further copied/distributed or hosted elsewhere without the express permission from National Academy of Sciences. 
showed that PSI was a good measure of physical road roughness, that appearance was extremely important to subjects' rating of ride quality, and that PSI, as measured in Wisconsin, either does not closely approximate the PSI from the Weaver/AASHO scale or the type of panel used in the study differs substantially from the panel selected from the AASHO road test. It was concluded that, to obtain the full benefit from this type of study, it would be essential to establish a criterion level of dissatisfaction and a percentage of road users who would be so dissatisfied (8).

In Minnesota, a panel of citizens was used in 1993 to help select a threshold of IRI (personal communication, Minnesota DOT personnel, 1996). The data, however, have yet to be used to define what represents a smooth or comfortable ride.

In summary, published studies to date have used quite small samples, have overlooked important variables such as traffic volume (highway classification), and have failed to investigate potential regional differences. Most notably, the studies cited above at best simply reported the correlation between objectively measured ride quality and driver satisfaction. Studies to date have failed to adequately provide a psychological model that explains what drivers perceive that leads to satisfaction. This study is the first to offer such an explanation.

\section{Developing a Model to Explain Driver Satisfaction}

A psychological theory was needed to explain the relationship between physical pavement characteristics and variation in driver satisfaction. To understand the relationship between the physical characteristics of the pavement and motorists' satisfaction with the pavement, the authors adapted relevant aspects of Fishbein's attitude model and Ajzen's theory of planned behavior (9-11). Both models propose that a person's attitude toward an object or behavior is based on a limited set (usually five to nine) of salient beliefs that the individual has toward that object or behavior. Each belief associates the object or behavior with a specific attribute or outcome. In addition, each attribute or outcome is usually evaluated as positive or negative (e.g., a good or bad outcome). In general, people weigh these beliefs

Transportation Research Record, Vol. 1769 (2001): pg. 61-70. DOI. This article is (C) National Academy of Sciences and permission has been granted for this version to appear in e-Publications@Marquette. National Academy of Sciences does not grant permission for this article to be further copied/distributed or hosted elsewhere without the express permission from National Academy of Sciences. 
and develop more favorable attitudes when they believe that, on balance, good outcomes are more likely and bad outcomes are less likely. They develop unfavorable attitudes when they perceive that bad outcomes are more likely and good outcomes less likely.

For example, a person's overall positive or negative attitude toward taking a vacation might be based on what he or she associates with the trip (e.g., would it probably be costly? relaxing?) adjusted by whether each outcome is seen as bad or good (e.g., is a costly trip a good one or a bad one?). A person mentally weighs the set of beliefs and evaluations (known collectively as "indirect attitude" or "cognitive structure") to develop an overall attitude about taking the trip. Beliefs and evaluations are formed by prior experience, information gained from others, and by inferences a person draws from experience and information.

The theory of planned behavior (an extension of expectancyvalue theory) has been used to assess drivers' attitudes toward specific driving violations (12-14). Griffeth and Rogers (15) used expectancy-value theory to study the effects of accident scene gruesomeness on student driver performance in driving simulators. In the published literature, expectancy-value theory has never been used to examine peoples' perceptions of pavement quality.

\section{Hypotheses}

This study was undertaken to determine the relative extent to which a motorist's attitude toward driving along a stretch of rural, twolane state highway is based on (a) the physical characteristics of the pavement and $(b)$ specific beliefs about the pavement. Figure 1 illustrates the hypothesized ordering of these variables in a simplified model. The components of the model are the physical pavement characteristics, cognitive structure as composed of salient beliefs about the act of driving on the pavement, and attitude operationalized as satisfaction with pavement characteristics. Knowing what motorists believe about the pavement will help policy makers determine what aspects of pavement quality are perceived by motorists and how those perceptions drive satisfaction with pavement quality.

Transportation Research Record, Vol. 1769 (2001): pg. 61-70. DOI. This article is (C) National Academy of Sciences and permission has been granted for this version to appear in e-Publications@Marquette. National Academy of Sciences does not grant permission for this article to be further copied/distributed or hosted elsewhere without the express permission from National Academy of Sciences. 
Although the concept of "cognitive structure" comes from Fishbein and Ajzen's theory of planned behavior, their theory goes well beyond the consideration of this concept $(11,12)$. Six other variables were included by the authors, and a full psychological model was tested to explain and understand additional variance in pavement satisfaction. Specifically, the following variables were included in the full model:

- Three demographic variables (education, gender, and age),

- Three experiential variables that served as controls (such as whether the participant drives a motorcycle, quality of vehicle ride, and frequency of driving the stretch of highway evaluated),

- Trust in the state DOT,

- The participant's perception of social pressures to avoid the stretch of highway evaluated,

- The participant's perceived control of being able to take an alternate route, and

- A set of highway characteristics (e.g., very hilly or curvy) unrelated to the pavement quality. The relations hypothesized in the full model are diagramed in Figure 2.

\section{Method}

The goal of the project, of which this analysis is a part, was to assess the perceptions of the pavements of rural, two-lane highways held by drivers in three Midwest states: Wisconsin, Iowa, and Minnesota (Kuemmel et al., this Record). The project was undertaken in three distinct phases. In Phase I, six focus groups were conducted in each state during the last half of 1996 to acquire qualitative data for the design of surveys. Each focus group consisted of 6 to 12 randomly solicited participants who were invited to participate in a structured discussion led by a trained moderator. Focus groups are usually conducted to collect qualitative information to be used in survey or questionnaire development. Specifically, the focus groups were designed $(a)$ to determine the beliefs and concerns that motorists have about these pavements and $(b)$ to determine the everyday language the public uses to describe and differentiate ruts, grooves, and other pavement characteristics so that these variables, in understandable language, can be included in statewide survey questionnaires. This approach, which employs an open-ended and more subjective

Transportation Research Record, Vol. 1769 (2001): pg. 61-70. DOI. This article is (C) National Academy of Sciences and permission has been granted for this version to appear in e-Publications@Marquette. National Academy of Sciences does not grant permission for this article to be further copied/distributed or hosted elsewhere without the express permission from National Academy of Sciences. 
technique to initially harvest relevant beliefs, is consistent with the method employed and recommended by Fishbein, Ajzen, and those who test their models. The results of the focus groups, guided by the theory-based, hypothesis-driven model, were used to develop questionnaires for the probability sample telephone surveys of motorists, which were conducted to assess the variables of interest in this study.

Phase II of the project consisted of telephone interviews of approximately 400 randomly selected motorists aged 18 or older in each state to pilot test general hypotheses and the psychometric properties of specific question sets. The three statewide surveys were administered in the fall of 1997 and completed in mid-December 1997. In this "pretest" phase, motorists were asked to self-select a local rural, two-lane highway for convenience. After driving the highway segment, participants completed a 25-min telephone survey consisting of 90 questions aimed at (a) determining satisfaction thresholds, $(b)$ describing policy and pavement improvement preferences, and $(c)$ testing the Fishbein and Ajzen models. Results indicated that the model was a very promising way of investigating the psychological dynamics related to motorist satisfaction with highway pavements. But it was also apparent that, for interpretive purposes, it is essential for the researchers to select a critical set of pavements with known characteristics (oversampling, for example, highways with poorer ride characteristics or those that are closer to the thresholds of motorist acceptance as judged from Phase II) in advance of the interviews. Simple random sampling would have yielded relatively few of these highway segments, which would in turn have constrained statistical power.

Thus, in Phase III, a stratified probability sample telephone survey, with more than twice as many respondents in each state, was conducted to develop thresholds of satisfaction and to test the model developed to predict motorist satisfaction. In this phase, highways were handpicked to ensure a sampling of highways of varying roughness that would be valuable for interpretive purposes.

Transportation Research Record, Vol. 1769 (2001): pg. 61-70. DOI. This article is (C) National Academy of Sciences and permission has been granted for this version to appear in e-Publications@Marquette. National Academy of Sciences does not grant permission for this article to be further copied/distributed or hosted elsewhere without the express permission from National Academy of Sciences. 
NOT THE PUBLISHED VERSION; this is the author's final, peer-reviewed manuscript. The published version may be accessed by following the link in the citation at the bottom of the page.

\section{Phase III Procedure}

Rural, two-lane highway segments were selected by the state DOTs across all quality ranges of physical pavement indices. Each segment was not under construction and was within $16 \mathrm{~km}$ (10 mi) of a city or village with a population greater than or equal to 500. Participants were randomly selected from telephone lists of each housing unit in the sample. Eligible respondents were screened via an initial phone call to locate persons willing to drive a specific 2 - to $5-\mathrm{km}$ (1- to 3-mi) section of local, rural, two-lane highway. The main survey was conducted via a second phone call after the respondents drove the specified highway segments. In the event a respondent could not do this, he or she was judged to be ineligible for the survey. Participants were recruited first, then surveyed after driving the preselected segment. This segment may or may not have been a route driven regularly by the driver.

\section{Sample}

The driver sample was a random-digit-dial sample of persons 18 years or older. The sample was approximately evenly split by gender in each state and normally distributed in terms of age. A majority of drivers in each state drove their assigned section of highway at least once per month. Approximately 25 percent of the participants in each state were college graduates. Income was not assessed at Phase III because it proved to be unrelated to driver satisfaction and other variables of interest in Phase II of the study.

\section{Measures}

\section{Pavement Indices}

Each state DOT provided its own physical pavement data. Wisconsin and Iowa provided physical data using IRI. Minnesota uses an index for ride called the Pavement Serviceability Rating (PSR), which is calculated from IRI. In all three states, the ride index correlated higher with satisfaction than any other condition index. The application of IRI or ride values for the purposes of pavement improvement and policy making is applied in each state somewhat

Transportation Research Record, Vol. 1769 (2001): pg. 61-70. DOI. This article is (C) National Academy of Sciences and permission has been granted for this version to appear in e-Publications@Marquette. National Academy of Sciences does not grant permission for this article to be further copied/distributed or hosted elsewhere without the express permission from National Academy of Sciences. 
differently based on that state's level of pavement service or quality provided. The interpretive quality guides used by the state DOTs are presented in Table 1.

\section{Satisfaction}

An overall index of pavement satisfaction was created by summing the following three separate five-point, Likert-scale (strongly agree to strongly disagree) questions asking about pavement satisfaction:

1. "I am satisfied with the pavement on this section of highway,"

2. "The pavement on this stretch of highway is better than most of the stretches of state highways I've driven in (Iowa)(Minnesota) (Wisconsin)," and

3. "The pavement on this section of highway should be improved" (reverse coded).

Reliability (Cronbach's alpha or a) for the unidimensional satisfaction index was quite satisfactory, averaging .85 across the three states. Cronbach's alpha is a measure of the internal consistency of the summated index based on how consistently respondents answered each of the three component questions (i.e., the extent to which greater agreement with each one of the component items corresponded with greater agreement with the others). Higher scores represent greater satisfaction on the overall index. Therefore the satisfaction index should have a negative zero-order (i.e., uncontrolled) relationship with IRI because higher scores on IRI represent rougher pavement. In contrast (for the state of Minnesota), the satisfaction index should have a positive zero-order (i.e., uncontrolled), direct relationship with PSR because higher scores represent better pavement conditions.

\section{Pavement Beliefs and Cognitive Structure}

Five commonly held beliefs about pavements were identified via focus groups in each of the three states. An analysis of focus group transcripts revealed the following five dimensions of belief, which were then turned into Likert-type items in the questionnaire:

Transportation Research Record, Vol. 1769 (2001): pg. 61-70. DOI. This article is (C) National Academy of Sciences and permission has been granted for this version to appear in e-Publications@Marquette. National Academy of Sciences does not grant permission for this article to be further copied/distributed or hosted elsewhere without the express permission from National Academy of Sciences. 
1. "Driving on the pavement on this section of highway causes extra wear on my vehicle's suspension system,"

2. "Driving on the pavement on this section of highway produces a bumpy ride,"

3. "Driving on the pavement on this section of highway causes me to focus my attention on the pavement surface,"

4. "Driving on the pavement on this section of highway is noisy,"

5. "The pavement on this section of highway looks patchy."

The five measures were summed to produce a single, unidimensional scale of cognitive structure with an average reliability that was superb ( $a=.88, .89$, and .89). Higher scores on this scale represent beliefs that the pavement is more problematic and of lower perceived quality along the dimensions noted. Therefore, cognitive structure should be positively related to IRI, and cognitive structure should be negatively related to PSR.

Normally, each of these beliefs would be multiplied by an evaluation of the outcome as provided by the respondent (e.g., the respondents would also be asked how "bad" or "good" extra wear on his or her vehicle's suspension system is) before being summed to produce the measure of cognitive structure. However, because focus group and pretest study results indicated that these beliefs had overwhelmingly negative evaluations (i.e., people overwhelmingly see these outcomes as bad), and consistent with Ajzen's procedure under these circumstances, the belief items were not multiplied by good-bad evaluations in the analysis but simply treated as though they were negative outcomes.

\section{Other Predictors-Expectancy Value Model}

Six sets of variables were included in the full model to account for variance in satisfaction above and beyond physical pavement indices and cognitive structure. The demographic, experiential, and nonpavement beliefs were included in the model as controls. Trust, subjective norms, and perceived behavioral control were included as part of the theory of planned behavior $(11,12)$.

Transportation Research Record, Vol. 1769 (2001): pg. 61-70. DOI. This article is @ National Academy of Sciences and permission has been granted for this version to appear in e-Publications@Marquette. National Academy of Sciences does not grant permission for this article to be further copied/distributed or hosted elsewhere without the express permission from National Academy of Sciences. 


\section{Demographic Variables}

Level of education, gender, and age were included in the model as controls. The following options were available for education: eighth grade education or less, some high school, high school graduate, some technical school or college, college graduate, post graduate college, or professional degree. Age was computed from the participants' reported year of birth.

\section{Driving Experience}

A person's driving experience can serve as a foundation for the development of his or her beliefs about pavement conditions. Three separate variables were used to reflect this experience: frequency of driving a motorcycle, the frequency of driving along the specific stretch of highway in question, and the self-reported quality of ride of his or her vehicle.

\section{Subjective Norms}

Adapted from Fishbein's and Ajzen's model, subjective norms reflect felt social pressures, specifically, what a person believes others think he or she should do. In adapting this measure from being a predictor of behavior to a predictor of attitude (satisfaction), the wording became "Most people whose opinions are important to me think that it is OK for me to drive this stretch of highway." It was reasoned that a person's own attitude could be affected by others who matter to him or her, especially if they express concern over the person's driving on a given stretch of road. Higher scores on this Likert-scaled item represent stronger agreement with the item.

\section{Perceived Trust}

Trust in the DOT might also affect satisfaction, at least by mitigating any anger that might be produced by driving along stretches of road with deteriorating pavement conditions. Trust was ascertained by summing respondent answers to four Likert-scaled items $(a=.66)$ : 
NOT THE PUBLISHED VERSION; this is the author's final, peer-reviewed manuscript. The published version may be accessed by following the link in the citation at the bottom of the page.

1. "The state DOT is capable of doing a good job of fixing and replacing pavements on rural highways in Wisconsin,"

2. "I trust the judgment of the state DOT when it comes to scheduling pavement improvements,"

3. "State DOT officials care about the safety and convenience of drivers on this stretch of road," and

4. "The DOT considers input from people like me when making decisions about repairs or improvements to this stretch of highway."

\section{Perceived Behavioral Control}

Adapted from Ajzen's model, it was expected that perceived behavioral control (PBC) could affect satisfaction. PBC reflects the amount of perceived control or voluntariness in a given behavior-in this case, driving along a given stretch of highway. Although PBC is usually a predictor of behavior, it was reasoned that motorists' responses to highway pavement conditions might be affected by whether they could chose an alternate route to travel. To measure PBC, responses were gathered on five-point, Likert-type scales to this item (Q55): "If I wanted to, I could easily find a convenient alternate route to the places I usually go instead of using this stretch of highway." Higher scores represent greater perceived control.

\section{Nonpavement Beliefs}

It was hypothesized that it would be important to consider nonpavement beliefs when attempting to understand driver satisfaction. Above and beyond pavement condition, beliefs people hold about the environment they experience when driving along a stretch of highway are predicted to be significantly related to satisfaction. Responses were again gathered via Likert-type scales to indicate whether the motorists believed that the stretch of highway in question was very hilly, was very curvy, was scenic, had a high volume of traffic, had pavement marking lines that were clear and easy to see, and made drivers feel comfortable pulling on to the shoulder if necessary.

Transportation Research Record, Vol. 1769 (2001): pg. 61-70. DOI. This article is (C) National Academy of Sciences and permission has been granted for this version to appear in e-Publications@Marquette. National Academy of Sciences does not grant permission for this article to be further copied/distributed or hosted elsewhere without the express permission from National Academy of Sciences. 


\section{Results}

\section{Cognitive Structure as an Intervening ("Explanatory") Variable}

The path analysis is a correlational technique that allows the researcher to determine the relative direct and indirect relations among three or more variables. The technique is most commonly used to test for mediation or moderation effects. The path analyses illustrated in Figure 3 indicate that cognitive structure does indeed mediate between pavement characteristics and satisfaction. Overall, the pattern of results replicates nicely across states (as well as replicates earlier findings from Phase II of the project). The results strongly suggest mediation. For example, in Wisconsin the statistically significant, zero-order (original) relationship between IRI and satisfaction $(\beta 1=-.19, p \leq .01)$ diminishes to near zero $(\beta=-.02, p$ is nonsignificant) when cognitive structure is entered into the path analysis as an intervening variable. The relationship between IRI and cognitive structure remains significant, as does the inverse relationship between cognitive structure and satisfaction. The beliefs that make up cognitive structure also seem to be reasonably comprehensive, at least to the extent that they intercept the beliefs that people can derive from the physical characteristics of the pavements as measured by IRI and PSR.

The strength of the relationships in Figure 3 suggests that this is a relatively concise model that works well. The relatively weak relationship between physical pavement indices and satisfaction seems indirect and (in these analyses) strongly mediated by a driver's beliefs about the pavement. Together, cognitive structure and IRI (or PSR) account for about 72 percent of the variance in satisfaction. These results illustrate the importance of the role that attitudes and beliefs play in driver satisfaction.

\section{Analysis of the Full Model}

Table 2 shows the results of the path analytic multiple regression analyses for the state of Wisconsin. Three separate 
analyses were conducted-one with each pavement type. The first analysis included both rigid and flexible pavements. The second and third analyses tested the model on these pavement types separately. IRI was used as the physical pavement index for each analysis. First, cognitive structure was regressed on the various blocks of predictor variables. Then satisfaction was regressed on the same blocks plus cognitive structure. The results tested the relationships illustrated in Figure 2 and showed how the relationships among the physical characteristics of the pavement, cognitive structure, and satisfaction may be affected by the other variables. Hierarchical multiple regression was used, with blocks of variables entered in the following order: (a) Demographic control variables-education, sex, and age; $(b)$ the set of experiential variables; $(c)$ the set of social variables; $(d)$ perceived behavioral control; $(e)$ the set of nonpavement beliefs; $(f)$ the physical pavement measure; and $(g)$ cognitive structure (for the regression of satisfaction only).

Results of the full model parallel those of the simplified model. Specifically, the physical measures $\Rightarrow$ cognitive structure $\Rightarrow$ satisfaction and relationships from Figure 3 remain in effect (albeit reduced in magnitude) even with controls for these sets of variables. For example, when looking at the analysis including all pavements (the two leftmost columns), the path from IRI to cognitive structure is .16 ( $p \leq .001)$, from cognitive structure to satisfaction $-.79(p \leq .001)$, and from IRI to satisfaction -.02 ( $p$ is nonsignificant). In summary, cognitive structure significantly reduces (i.e., mediates) the relationship between physical pavement characteristics and satisfaction. Thus, the basic model holds, even with rigorous controls. These results were strongly replicated across all three states in both Phase II and Phase III of the study (Kuemmel et al., this Record). Overall, the set of predictor variables account for up to 22 percent of the variance (see adjusted $R 2$ in Table 2) in cognitive structure and 73 percent of the variance in satisfaction.

\section{Microscope Analysis of the Model}

To diagnose the dynamics of the relationships in the physical measures $\Rightarrow$ cognitive structure $\Rightarrow$ satisfaction chain, the team conducted analyses of the relationships among the individual items

Transportation Research Record, Vol. 1769 (2001): pg. 61-70. DOI. This article is @ National Academy of Sciences and permission has been granted for this version to appear in e-Publications@Marquette. National Academy of Sciences does not grant permission for this article to be further copied/distributed or hosted elsewhere without the express permission from National Academy of Sciences. 
that make up the cognitive structure and satisfaction indexes. Partial correlation coefficients in Table 3 indicate that overall (dis)satisfaction appears to be most affected by the beliefs that the pavement produces a bumpy ride (average across-state partial $r=-.71, p \leq .001$ ) and causes extra wear on one's vehicle's suspension system (average across-state partial $r=-.67, p \leq .001$ ). Consistently (i.e., across states), beliefs about diversion of attention to the road surface play a somewhat less, but still significant, role in overall satisfaction.

A microscopic analysis of the relationships between both physical pavement measurements and pavement beliefs (components of cognitive structure) is shown in Table 4. Each pavement index (IRI and PSR) was significantly related to each of the five beliefs that make up cognitive structure, even after controlling for several control variables. Cognitive structure was most highly related with IRI for Iowa (partial $r=.26, p \leq .001$ ), followed by PSR for Minnesota (partial $r=-.22, p \leq .001$ ), and IRI for Wisconsin (partial $r=.18, p \leq .001$ ).

The size of this difference between these partial correlations is slight to moderate. The strengths of the relationships are suspected to be related to the degree to which the state DOTs could describe clues about the segment limits that had to be communicated to the participants recruited by telephone and confirmed during the initial interview as to its location.

\section{Discussion and Conclusion}

The analyses presented in this paper about motorists' perceptions of pavement conditions has unveiled and applied a robust and concise psychological model that explains how drivers evaluate the quality of pavements. In each state, the direct relationship between pavement quality and driver satisfaction was mediated by cognitive structure-a set of five specific beliefs about the pavement.

The small to moderate bivariate correlations found between physical pavement indices and driver satisfaction did not surprise the authors. In fact, the research team predicted that the direct relationship would be small because of the psychologically complex nature of satisfaction. First, the small relationship can be partially attributed to drivers having dissimilar ideas of what constitutes a 
pavement in acceptable condition. Some drivers had very high expectations and were dissatisfied with highways in very good condition. Other drivers were content with highways in very poor condition. The great variance in what drivers find personally acceptable necessarily lowers the direct relationship between IRI and satisfaction. Secondly, the central hypothesis to this paper is that physical pavement indices influence what drivers' perceive and, in turn, these perceptions serve as the basis for the formation of salient beliefs about the pavement (e.g., the pavement produces a bumpy ride, is noisy, and so forth). A strong direct correlation between IRI and satisfaction might have been expected in this study if motorists could restrict the information they used in the formation of beliefs about the pavement to the sensory input they experienced while driving the requested stretch of highway. However, beliefs tend to be formed by a broad range of factors, such as prior experience, information gained from others, and inferences a person draws from experience and information. These factors commonly play a role in the formation of beliefs and attitudes $(11,12)$ and would necessarily distort the IRI $\Rightarrow$ cognitive structure $\Rightarrow$ satisfaction relationship. Lastly, the theory of planned behavior suggests that one's attitude (and in this study, satisfaction with the pavement) is a result of a host of other variables, such as, for example, a perceived social pressure. The results of this study are consistent with the theory and illustrate quite well the myriad of psychological factors (each with their own precursors) that stand between IRI and pavement satisfaction.

IRI shared less than 4 percent of the variance with driver satisfaction. By contrast, the full model predicted 73 percent of the variance in pavement satisfaction. Variables in the full model that were consistently found to predict satisfaction were (a) pavement beliefs representing cognitive structure; $(b)$ trust in the DOT; $(c)$ subjective norm; and $(d)$ nonpavement beliefs that the highway has low traffic, comfortable shoulders, and clear pavement markings. Clearly, this study illustrates the importance of considering psychological phenomena, such as attitudes and beliefs, when attempting to understand driver satisfaction.

This study has made a number of other contributions to field. First, this study offers a reliable measure of "driver satisfaction." The

Transportation Research Record, Vol. 1769 (2001): pg. 61-70. DOI. This article is @ National Academy of Sciences and permission has been granted for this version to appear in e-Publications@Marquette. National Academy of Sciences does not grant permission for this article to be further copied/distributed or hosted elsewhere without the express permission from National Academy of Sciences. 
three-question index of satisfaction proved to have good internal consistency (minimum $a=.84$ ), and the scale's significant bivariate correlations with the states' pavement indices (which ranged from .19 to .36, from Figure 3) suggest initial construct validity. Although these correlations are moderate in magnitude at best, one would not expect to find very strong direct correlations between pavement indices and satisfaction. It was hypothesized that a person's beliefs about the pavement account for much of the variance in satisfaction. Indeed, these results support this conclusion. Future studies of the public's perception of pavement quality can use or refine the three questions used in this study to measure pavement satisfaction. It is also hoped that the state DOTs will use this measure in field research to assess "driver satisfaction," that is

- "I am satisfied with the pavement on this section of highway,"

- "The pavement on this stretch of highway is better than most of the stretches of state highways I've driven in this state," and

- "The pavement on this section of highway should be improved" (reverse coded).

In addition, this study has accomplished the important task of identifying the most salient pavement features considered by the public when they evaluate pavement quality. This sheds important insight into what motorists consider and how. Specifically, the aspect of perceived highway pavement quality that motorists seem to consider most heavily is the belief that the pavement causes a bumpy ride. In each state, this belief was most highly related to satisfaction. This belief was followed in magnitude of relationship to satisfaction by the motorist's belief that the pavement causes extra wear on the vehicle's suspension system.

Most importantly, the study illustrates very clearly the importance of considering "beliefs" about the pavement when trying to predict or understand driver satisfaction. The strength of the correlations between physical pavement condition and satisfaction among the states average .28 (Figure 3), less than half the magnitude of those between individual beliefs about the pavement and satisfaction, which average .63 (Table 3). The high relationship

Transportation Research Record, Vol. 1769 (2001): pg. 61-70. DOI. This article is (C) National Academy of Sciences and permission has been granted for this version to appear in e-Publications@Marquette. National Academy of Sciences does not grant permission for this article to be further copied/distributed or hosted elsewhere without the express permission from National Academy of Sciences. 
between beliefs and satisfaction has potentially important policy implications for state DOTs interested in developing and maintaining driver satisfaction. In general, beliefs and evaluations are formed by prior experience, information gained from others, and inferences a person draws from experience and information. Specifically, there may be rare instances in which it may be more cost-effective to provide drivers with accurate information about a road's condition relative to other roads in the state or nation. Such information could be provided for aspects of the pavement about which there is a noteworthy incongruence between the public's belief about that road and the actual pavement condition (e.g., the pavement is bumpy, noisy, and so forth).

\section{Acknowledgments}

This study was funded by a Pooled Fund Project of the Iowa, Minnesota, and Wisconsin DOTs. The authors would like to thank FHWA and the many DOT personnel from each state who supported the research team. Specifically, they would like to thank Steve Shober and Bob Schmiedlin, retired from the Wisconsin DOT, for their help and support in taking the lead to get this project started and supporting it for the 5 years it has been under way. Further credit is due the Wisconsin Survey Research Lab and its many staff members for their excellent cooperation in completing all the survey work in a timely fashion.

\section{References}

1. Khisty, C. J., and S. Leleur. Citizen Participation Through Communicative Action: Towards a New Framework and Synthesis. Journal of Advanced Transportation, Vol. 31, No. 2, Summer 1997, pp.119-137.

2. Haas, R., and W. R. Hudson. Defining and Serving Clients for Pavements. In Transportation Research Record 1524, TRB, National Research Council, Washington, D.C., 1996, pp. 1-9.

3. Robinson, R. K., D. A. Kuemmel, R. C. Sonntag, S. F. Shober, and R. J. Griffin. Public Perceptions of Wisconsin Pavements and Trade-Offs in Pavement Improvement. Transportation Research Record: Journal of the Transportation Research Board, No. 1699, TRB, National Research Council, Washington, D.C., 2000, pp. 66-71.

Transportation Research Record, Vol. 1769 (2001): pg. 61-70. DOI. This article is (C) National Academy of Sciences and permission has been granted for this version to appear in e-Publications@Marquette. National Academy of Sciences does not grant permission for this article to be further copied/distributed or hosted elsewhere without the express permission from National Academy of Sciences. 
NOT THE PUBLISHED VERSION; this is the author's final, peer-reviewed manuscript. The published version may be accessed by following the link in the citation at the bottom of the page.

4. AASHO Road Test: Summary Report, Report 7. HRB, National Research Council, Washington, D.C., 1962.

5. Briefing Paper PSI to IRI Conversion. Wisconsin Department of Transportation, Madison, 1993.

6. Correlation of IRI to Public Perception of Pavement Roughness. Indiana Department of Transportation, Division of Research, West Lafayette, 1993.

7. Arterburn, S., and B. Suprenant. Public Perception of Pavement Rideability. Report CDOH-UCB-R-90-10. Colorado Department of Highways, Denver, 1990.

8. Garg, A., A. Horowitz, and F. Ross. Establishing Relationships Between Pavement Roughness and Perceptions of Acceptability. Transportation Research Record 1196, TRB, National Research Council, Washington, D.C., 1988 , pp. 276-285.

9. Ajzen, I. Attitudes, Personality, and Behavior. Dorsey Press, Chicago, Ill., 198

10. Ajzen, I., and M. Fishbein. Understanding Attitudes and Predicting Social Behavior. Prentice Hall, Englewood Cliffs, N.J., 1980.

11. Fishbein, M., and I. Ajzen. Belief, Attitude, Intention, and Behavior: An Introduction to Theory and Research. Addison-Wesley, Reading, Mass., 1975.

12. Parker, D., A. S. R. Manstead, S. G. Stradling, J. T. Reason. Intention to Commit Driving Violations: An Application of the Theory of Planned Behavior. Journal of Applied Psychology, Vol. 77, 1992, pp. 94-101.

13. Parker, D., S. G. Stradling, A. S. Manstead. Extending the Theory of Planned Behavior: The Role of Personal Norm. British Journal of Social Psychology, Vol. 34, No. 2, June 1995, pp. 127-137.

14. Parker, D., S. G. Stradling, A. S. Manstead. Modifying Beliefs and Attitudes to Exceeding the Speed Limit: An Intervention Study Based on the Theory of Planned Behavior. Journal of Applied Psychology, Vol. 26, No. 1, June 1996, pp. 1-19.

15. Griffeth, R. W., and R. W. Rogers. Effects of Fear-Arousing Components of Driver Education on Students' Safety Attitudes and Simulator Performance. Journal of Educational Psychology, Vol. 68, No. 4, Aug. 1976, pp. 501-506.

Transportation Research Record, Vol. 1769 (2001): pg. 61-70. DOI. This article is (C) National Academy of Sciences and permission has been granted for this version to appear in e-Publications@Marquette. National Academy of Sciences does not grant permission for this article to be further copied/distributed or hosted elsewhere without the express permission from National Academy of Sciences. 
NOT THE PUBLISHED VERSION; this is the author's final, peer-reviewed manuscript. The published version may be accessed by following the link in the citation at the bottom of the page.

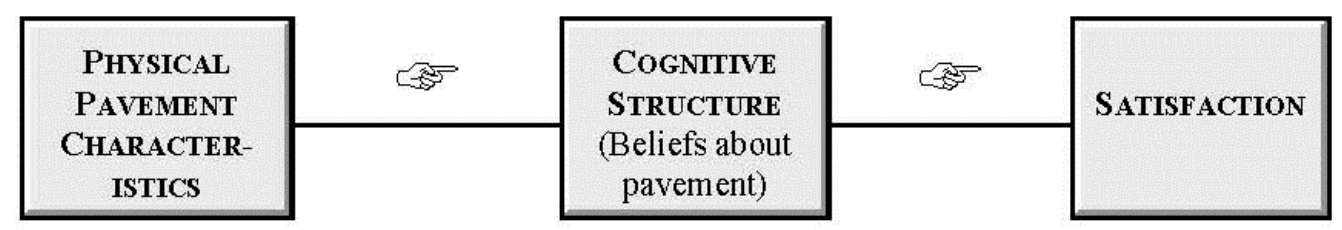

FIGURE 1 Simplified model showing cognitive structure as an intervening variable between physical pavement characteristics and satisfaction with pavements.

\section{Perceived \\ Behavioral \\ Control}
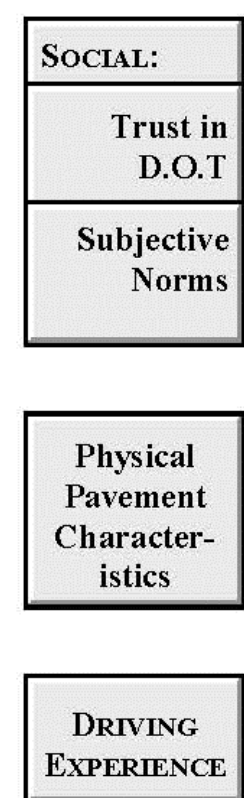

DEMO-

GRAPHIC

VARIABLES

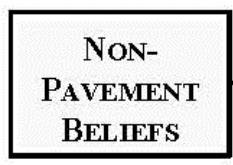

FIGURE 2 Full psychological model showing hypothesized predictors of satisfaction with pavement conditions.

Transportation Research Record, Vol. 1769 (2001): pg. 61-70. DOI. This article is (C) National Academy of Sciences and permission has been granted for this version to appear in e-Publications@Marquette. National Academy of Sciences does not grant permission for this article to be further copied/distributed or hosted elsewhere without the express permission from National Academy of Sciences. 
NOT THE PUBLISHED VERSION; this is the author's final, peer-reviewed manuscript. The published version may be accessed by following the link in the citation at the bottom of the page.

TABLE 1 Interpretive Categories for Pavement Indices Used by State DOTs

\begin{tabular}{lllllll}
\hline $\begin{array}{llllll}\text { IRI used by Wisconsin } \\
\text { DOT }\end{array}$ & & \multicolumn{3}{c}{ IRI used by Iowa DOT } & & \multicolumn{2}{l}{$\begin{array}{l}\text { PSR (ride) } \\
\text { used by Minnesota DOT }\end{array}$} \\
Range & $\begin{array}{l}\text { Interpretive } \\
\text { Category }\end{array}$ & Range & $\begin{array}{l}\text { Interpretive } \\
\text { Category }\end{array}$ & Range & $\begin{array}{l}\text { Interpretive } \\
\text { Category }\end{array}$ \\
\hline $0.00-1.44$ & Very Good & $0.00-1.4$ & Very Good & 5.0 to 3.7 & Very Good \\
$1.45-1.80$ & Good & $1.41-2.2$ & Good & 3.6 to 3.3 & Good \\
$1.81-2.25$ & Fair & $2.21-3.0$ & Fair & 3.2 to 2.9 & Fair \\
$2.26-2.90$ & Poor & $3.01-3.80$ & Poor & 2.8 to 0 & Poor \\
$>2.90$ & Very Poor & $>3.81$ & Very Poor & & \\
\hline
\end{tabular}

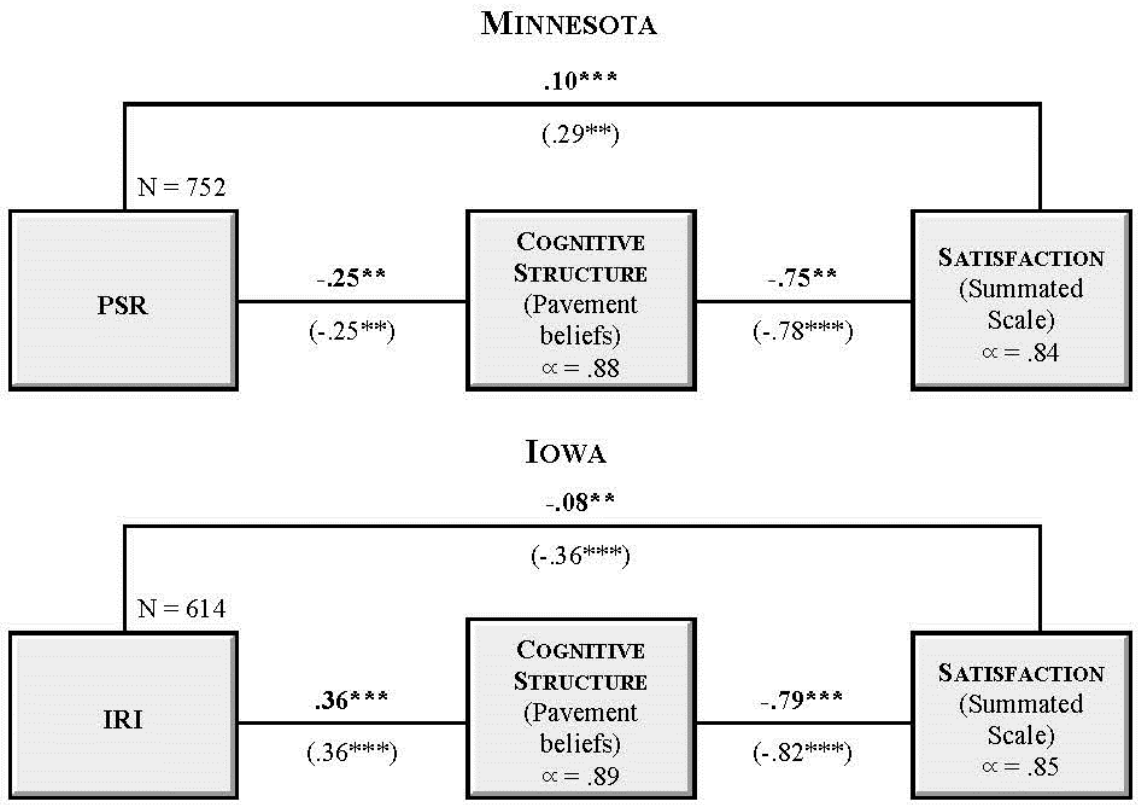

WISCONSIN

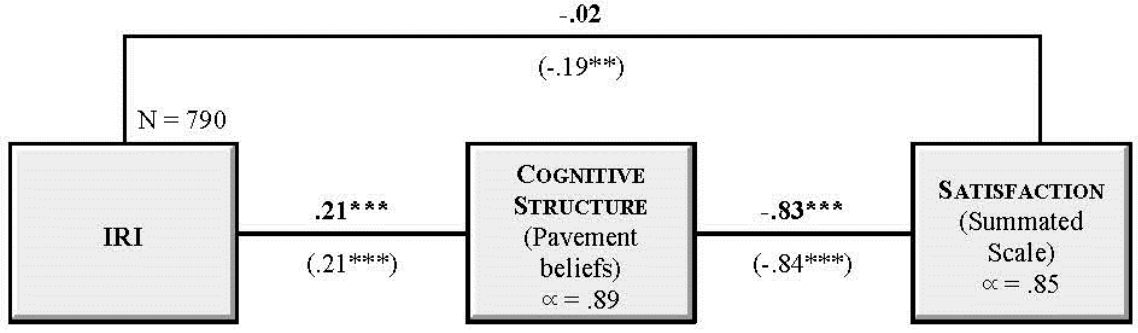

FIGURE 3 Path analysis showing cognitive structure as intervening variable between physical pavement characteristics and satisfaction. (Coefficients in bold are path coefficients. Coefficients in parentheses are zero-order _ coefficients. Two-tailed significance key: $* p \leq .05$;

$* * p \leq .01 ; * * * p \leq .001$.)

Transportation Research Record, Vol. 1769 (2001): pg. 61-70. DOI. This article is (C) National Academy of Sciences and permission has been granted for this version to appear in e-Publications@Marquette. National Academy of Sciences does not grant permission for this article to be further copied/distributed or hosted elsewhere without the express permission from National Academy of Sciences. 
NOT THE PUBLISHED VERSION; this is the author's final, peer-reviewed manuscript. The published version may be accessed by following the link in the citation at the bottom of the page.

TABLE 2 Relationship of Control Variables and Wisconsin IRI to Cognitive Structure and Satisfaction with Pavement Conditions (Full Model)

\begin{tabular}{|c|c|c|c|c|c|c|}
\hline \multirow[b]{2}{*}{ DEPENDENT VARIABLE: } & \multicolumn{2}{|c|}{ All Pavements } & \multicolumn{2}{|c|}{ Flexible Only } & \multicolumn{2}{|c|}{ Rigid Only } \\
\hline & $\begin{array}{c}\text { Cognitive } \\
\text { Structure } \\
\propto=.89\end{array}$ & $\begin{array}{c}\text { Satis- } \\
\text { faction } \\
\propto=.85\end{array}$ & $\begin{array}{l}\text { Cognitive } \\
\text { Structure }\end{array}$ & $\begin{array}{l}\text { Satis- } \\
\text { faction }\end{array}$ & $\begin{array}{l}\text { Cognitive } \\
\text { Structure }\end{array}$ & $\begin{array}{c}\text { Satis- } \\
\text { faction }\end{array}$ \\
\hline \multicolumn{7}{|l|}{ DEMOGRAPHIC: } \\
\hline Education & -.03 & -.02 & -.01 & -.01 & .00 & -.07 \\
\hline Female Sex & -.01 & -.01 & -.05 & -.00 & .04 & .05 \\
\hline Age & -.02 & -01 & -.03 & -.02 & -.00 & -.00 \\
\hline$R^{2}$ change & .00 & .00 & .00 & .00 & .00 & .01 \\
\hline \multicolumn{7}{|l|}{ EXPERIENT IAL: } \\
\hline Cycle driving frequency & .05 & -.03 & .09 & -.04 & -.04 & .01 \\
\hline Vehicle ìridê̂ & .07 & -.04 & .05 & -.03 & .12 & -.08 \\
\hline Frequency of driving stretch & .02 & -.02 & .04 & -.03 & -.03 & .02 \\
\hline$R^{2}$ change & .01 & .00 & .01 & .00 & .02 & .01 \\
\hline \multicolumn{7}{|l|}{ SOCIAL: } \\
\hline Trust in transp ortation dept. $\propto=66$ & -.05 & $.14^{* * *}$ & -.04 & $.11^{* * *}$ & -.09 & $.20^{* * *}$ \\
\hline Subjective norms & $-.35^{* * *}$ & $.35^{* * *}$ & $-.38^{* * *}$ & $.40^{* * *}$ & $-.29^{* * *}$ & $.27^{* * *}$ \\
\hline$R^{2}$ change & $.13^{* * *}$ & $.17^{* * *}$ & $.15^{* * *}$ & $.19^{* * *}$ & $.10^{* * *}$ & $.13^{* * *}$ \\
\hline PERCEIVED BEHAVIORAL CONTROL & -.01 & .05 & -.01 & .06 & .01 & .02 \\
\hline$R^{2}$ change & .00 & .00 & .00 & .00 & .00 & .00 \\
\hline \multicolumn{7}{|l|}{ NON-PAVEMENT BELIEFS } \\
\hline Very hilly & $.08^{* *}$ & -.06 & .08 & -.05 & .11 & -.12 \\
\hline Very curvy & .01 & .05 & .00 & .06 & .04 & .04 \\
\hline Scenic & -.01 & .00 & -.02 & .00 & -.04 & .04 \\
\hline High traffic volume & $.15^{* * *}$ & $-.11^{* * *}$ & $.14^{* * *}$ & $-.10^{* *}$ & $.16^{* * *}$ & $-.17^{* *}$ \\
\hline Comfortable shoulders & $-.08^{*}$ & $.15^{* * *}$ & -.07 & $.14^{* * *}$ & $-.19^{* *}$ & $.19^{* *}$ \\
\hline Clear pavement markings & $-.18^{* * *}$ & $.17^{* * *}$ & $-.25^{* * *}$ & $.22^{* * *}$ & .03 & .03 \\
\hline$R^{2}$ change & $.07^{* * *}$ & $.07 * * *$ & $.09^{* * *}$ & $.08^{* * *}$ & $.08^{* * *}$ & $.07^{* * *}$ \\
\hline INTERNATIONAL ROUGHNESS INDEX (IRI) & $.16^{* * *}$ & -.02 & $.10^{* *}$ & .01 & $.34^{* * *}$ & -.03 \\
\hline$R^{2}$ change & $.02^{* * *}$ & .01 & $.01^{* *}$ & .01 & $.10^{* * *}$ & .01 \\
\hline COGNITIVE STRUCTURE & & $-.79^{* * *}$ & & $-.77^{* * *}$ & & $-.79^{* * *}$ \\
\hline$R^{2}$ change & & $.47^{* * *}$ & & $.44^{* * *}$ & & $.44^{* * *}$ \\
\hline Multiple R & $.49^{* * *}$ & $.86^{* * *}$ & $.52^{* * *}$ & $.85^{* * *}$ & $.55^{* * *}$ & $.88^{* * *}$ \\
\hline \multirow[t]{2}{*}{ Adjusted $\mathrm{R}^{2}$} & .22 & .73 & .25 & .72 & .24 & .76 \\
\hline & 790 & 790 & 583 & 583 & 207 & 207 \\
\hline
\end{tabular}

Two-tailed significance key: * $p \leq .05 ; * * p \leq .01 ; * * * p \leq .001$. Coefficients in the body of this table are $\beta$ coefficients, which are like a correlation coefficient and can range from -1 to +1 . Betas are the product of a regression analysis in which the measures are standardized.

Transportation Research Record, Vol. 1769 (2001): pg. 61-70. DOI. This article is (C) National Academy of Sciences and permission has been granted for this version to appear in e-Publications@ Marquette. National Academy of Sciences does not grant permission for this article to be further copied/distributed or hosted elsewhere without the express permission from National Academy of Sciences. 
NOT THE PUBLISHED VERSION; this is the author's final, peer-reviewed manuscript. The published version may be accessed by following the link in the citation at the bottom of the page.

TABLE 3 Relationship of Pavement Beliefs to Satisfaction

\begin{tabular}{|c|c|c|c|c|}
\hline & \multicolumn{4}{|c|}{ Summated Satisfaction Index ${ }^{a, b}$ : } \\
\hline & $\begin{array}{l}\text { Minnesota } \\
\mathrm{N}=752\end{array}$ & $\begin{array}{l}\text { Iowa } \\
N=676\end{array}$ & $\begin{array}{l}\text { Wisconsin } \\
\mathrm{N}=690\end{array}$ & $\begin{array}{l}\text { Numerical } \\
\text { Average }\end{array}$ \\
\hline \multicolumn{5}{|l|}{ PAVEMENT BELIEFS $^{a}$} \\
\hline \multicolumn{5}{|l|}{$\begin{array}{l}\text { Driving on the pavement on this } \\
\text { section of highway.... }\end{array}$} \\
\hline $\begin{array}{l}\text {...Causes extra wear on my vehicle's } \\
\text { suspension system. }\end{array}$ & $-.63 * * *$ & $-.66 * * *$ & $-.72 * * *$ & $-.67 * * *$ \\
\hline ...Produces a bumpy ride. & $-.69 * * *$ & $-.70 * * *$ & $-.74 * * *$ & $-.71 * * *$ \\
\hline $\begin{array}{l}\text {...Causes me to focus my attention } \\
\text { on the pavement surface. }\end{array}$ & $-.41 * * *$ & $-.54 * * *$ & $-.52 * * *$ & $-.49 * * *$ \\
\hline ...Is noisy. & $-.62 * * *$ & $-.60 * * *$ & $-.66 * * *$ & $-.63 * * *$ \\
\hline The pavement looks patchy. & $-.63 * * *$ & $-.66 * * *$ & $-.62 * * *$ & $-.64 * * *$ \\
\hline $\begin{array}{l}\text { COGNITIVE STRUCTURE } \\
\text { (summated pavement beliefs) average } \propto=.89\end{array}$ & $-.75 * * *$ & $-.79 * * *$ & $-.80 * * *$ & $-.78 * * *$ \\
\hline
\end{tabular}

Two-tailed significance key: $* p \leq .05 ; * * p \leq .01 ; * * * p \leq .0011$. The coefficients in this table are fifteenth-order partials controlled by education, sex, age, cycle driving frequency, vehicle "ride," frequency of driving stretch of highway, trust in transportation department, subjective norms, perceived behavioral control, and the set of six non-pavement beliefs. They are not controlled by physical pavement characteristics.

aBeliefs and satisfaction items are scaled such that greater agreement produces higher numerical values.

bScoring of the item "the pavement...should be improved" was reversed in the calculation of the summated index.

Transportation Research Record, Vol. 1769 (2001): pg. 61-70. DOI. This article is (C) National Academy of Sciences and permission has been granted for this version to appear in e-Publications@Marquette. National Academy of Sciences does not grant permission for this article to be further copied/distributed or hosted elsewhere without the express permission from National Academy of Sciences. 
NOT THE PUBLISHED VERSION; this is the author's final, peer-reviewed manuscript. The published version may be accessed by following the link in the citation at the bottom of the page.

TABLE 4 Relationship of Pavement Beliefs to Physical Pavement Measures

\begin{tabular}{|c|c|c|c|}
\hline & \multicolumn{3}{|c|}{ State and Physical Pavement Measure } \\
\hline & Minnesota (PSR) & Iowa (IRI) & Wisconsin (IRI) \\
\hline PAVEMENT BELIEFS $^{a}$ & & & \\
\hline $\begin{array}{l}\text { Driving on the pavement on this } \\
\text { section of highway.... }\end{array}$ & & & \\
\hline $\begin{array}{l}\text {...Causes extra wear on my vehicle's } \\
\text { suspension system. }\end{array}$ & $-.17 * * *$ & $.22 * * *$ & $.14 * * *$ \\
\hline ...Produces a bumpy ride. & $-.23 * * *$ & $.22 * * *$ & $.18^{* * *}$ \\
\hline $\begin{array}{l}\text {...Causes me to focus my attention } \\
\text { on the pavement surface. }\end{array}$ & $-.16 * * *$ & $.18^{* * *}$ & $.13^{* * *}$ \\
\hline ....Is noisy. & $-.15 * * *$ & $.18 * * *$ & $.16^{* * *}$ \\
\hline The pavement looks patchy. & $-.18 * * *$ & $.25 * * *$ & $.11 * * *$ \\
\hline $\begin{array}{l}\text { COGNITIVE STRUCTURE } \\
\text { (summated pavement beliefs) Average } \propto=.89\end{array}$ & $-.22 * * *$ & $.26^{* * *}$ & $.18^{* * *}$ \\
\hline $\mathrm{N}=$ & 752 & 614 & 690 \\
\hline
\end{tabular}

Two-tailed significance key: ${ }^{*} p \leq .05 ;{ }^{* *} p \leq .01 ;{ }^{* * *} p \leq .001$. Fifteenth-order partials controlled by eduaction, sex, age, cycle driving frequency, vehicle "ride," frequency of driving stretch of highway, trust in transportation department, subjective norms, perceived behavioral control, and the set of six nonpavement beliefs.

${ }^{a}$ Beliefs are scaled such that greater agreement produces higher numerical values.

Transportation Research Record, Vol. 1769 (2001): pg. 61-70. DOI. This article is (C) National Academy of Sciences and permission has been granted for this version to appear in e-Publications@Marquette. National Academy of Sciences does not grant permission for this article to be further copied/distributed or hosted elsewhere without the express permission from National Academy of Sciences. 